\title{
Comparison of pear production areas from yield risk aspect
}

\author{
Persely, Sz. ${ }^{1}$, Ladányi, M. ${ }^{2}$, Nyéki, J. ${ }^{3}$, Szabó, Z. ${ }^{3}$, Soltész, M. ${ }^{3}$ \& Ertsey, I. ${ }^{1}$ \\ ${ }^{1}$ University of Debrecen, Centre for Agricultural Sciences and Engineering, Department of Economic Analysis \\ and Statistics, H-4032 Debrecen, 138 Böszörményi, Hungary, E-mail: suto@agr.unideb.hu \\ ${ }^{2}$ Corvinus University of Budapest, Department of Mathematics and Informatics, H-1118 Budapest, 29-43 Villányi, \\ Hungary, E-mail: marta.ladanyi@uni-corvinus.hu \\ ${ }^{3}$ Institute for Research and Development, University of Debrecen, H-4032 Debrecen, 138 Böszörményi, Hungary, \\ E-mail:nyeki@agr.unideb.hu
}

\begin{abstract}
Summary: There are three main pear production regions in Hungary. The most relevant is the West-Transdanubian (Zala, Vas and Győr-MosonSopron counties), where up to $30 \%$ of total pear production occurs. The second most productive region is Pest County, where pear is grown mostly in gardens and garden plots, resulting in 15-20\% of Hungarian production. In the northern Hungarian region (Bodrog valley in BorsodAbaúj-Zemplén, Heves and Nógrád counties), the microclimate is perfect for optimal pear production. In our analysis, we focused on four plantations that are dominant in pear production in Hungary. Two of them are situated in south-western Hungary, one of them is in South Transdanubia and one is in North Hungary. Considering the personal attitude of the decision maker towards risk, the best alternative is 'Williams' in Alsóberecki, as the yield risk is the lowest with this variety, while the second best alternative is 'Bosc Beurre,' also produced in Alsóberecki. This is an irrigated area, and this fact evidently decreases the yield risk. The highest risk is in Bánfapuszta and in Zalasárszeg, for the non-irrigated 'Williams' variety. The highest yield with the lowest risk can be obtained with irrigation. Nevertheless, in the case that relevant data are available, and by incorporating cost and expected profit data, the stochastic dominance method is suitable for financial risk assessment, as well.
\end{abstract}

Key words: pear, yield, mean-variation efficiency, stochastic dominance

\section{Introduction}

Hungary does not number among the greatest European pear producing counties. The area of pear plantations is only $8-10 \%$ the size of the total area of the apple orchards. Earlier, between 1981 and 1984, 100 thousand tonnes of pears were harvested and during this boom, similarly to the European pattern, varieties were cultivated which could handle higher levels precipitation and humidity. Since 1985 , production has been decreasing. While in 1985, 10900 ha were used as pear plantations, this figure was 13800 ha in 1994 and 3200 ha in 2007 (FAO). Plantations are mainly situated in southern Hungary and West-Transdanubia. In West-Transdanubia, almost one-half of the plantations exceed 25 ha, while they are predominantly between 10 and 15 ha in the south $(K S H)$. The most important varieties are 'Bosc Beurre' (32\%) and 'Williams' (18.5\%), followed by 'Conference' and 'Packhams'. In Europe, the yearly average consumption per capita for pear is $5 \mathrm{~kg}$ and only $1.5 \mathrm{~kg}$ in Hungary. Hungarian producers would like of course to reach levels of domestic consumption more on a par with that in the rest of Europe. For this wider range variety selection, improved production and processing technology are necessary. Drimba and Nagy (1997, 1998, 2000), as well as Drimba and Ertsey (2003) pointed out that yield risk has an important role in production. Our aim was to compare four different plantations with different agro-ecological characteristics, together with two different pear varieties ('Bosc Beurre' and 'Williams') from the aspect of yield risk and considering the personal attitude of the decision-maker towards risk.

\section{Material and methods}

\section{The examined fruit varieties}

\section{- 'Bosc Beurre'}

'Bosc Beurre' is the most widely cultivated variety in Hungary. It is well-known worldwide, with its distinctive characteristics being its brown skin, which holds a delicious, sweet-spicy flavoured and slightly firmer flesh, which while a bit crunchy, remains tender. It has a long, curved stem with a neck that widens gradually into a round shape (Göndörné, 2000). Russetting may cover the entire surface of the pear (Soltész, 1998). Harvest is usually in mid September. The tree is medium sized or slightly weak. The size of the fruit is large or extra large (180-280 g), showing little colour change as it ripens.

\section{- 'Williams'}

In Hungary, this is the second most important variety after the 'Bosc Beurre'. It has a classical "pear shape": a rounded bell on the bottom half of the fruit, with a definitive shoulder and a smaller neck or stem end (Göndörné, 2000, 


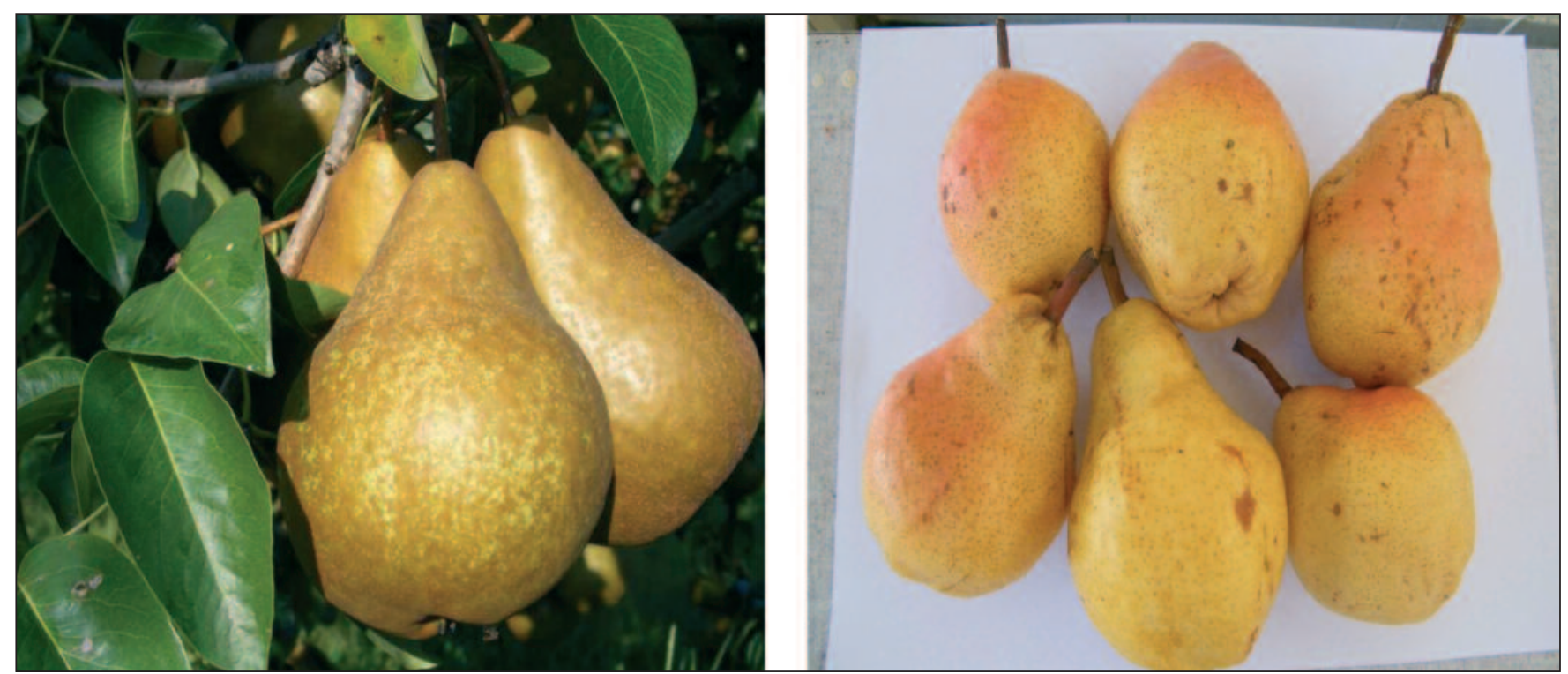

Figure 1. The examined pear varieties ('Bosc Beurre' and 'Williams')

2001). This pear is extremely aromatic. The size of the fruit is large or extra large (160-220 g) (Soltész, 1998). It is harvested from late August to early September. This pear is unique, in that its skin colour brightens as it ripens, unlike other varieties. Its flavour is sweet delicious when it reaches a golden yellow ripening stage. In addition to eating it fresh for its smooth texture, 'Williams' is also traditionally known as a canning pear variety.

\section{The examined plantations}

\section{- Zalasárszeg}

The Zalasárszeg plantation is situated in south-western Hungary. There are 45 ha of

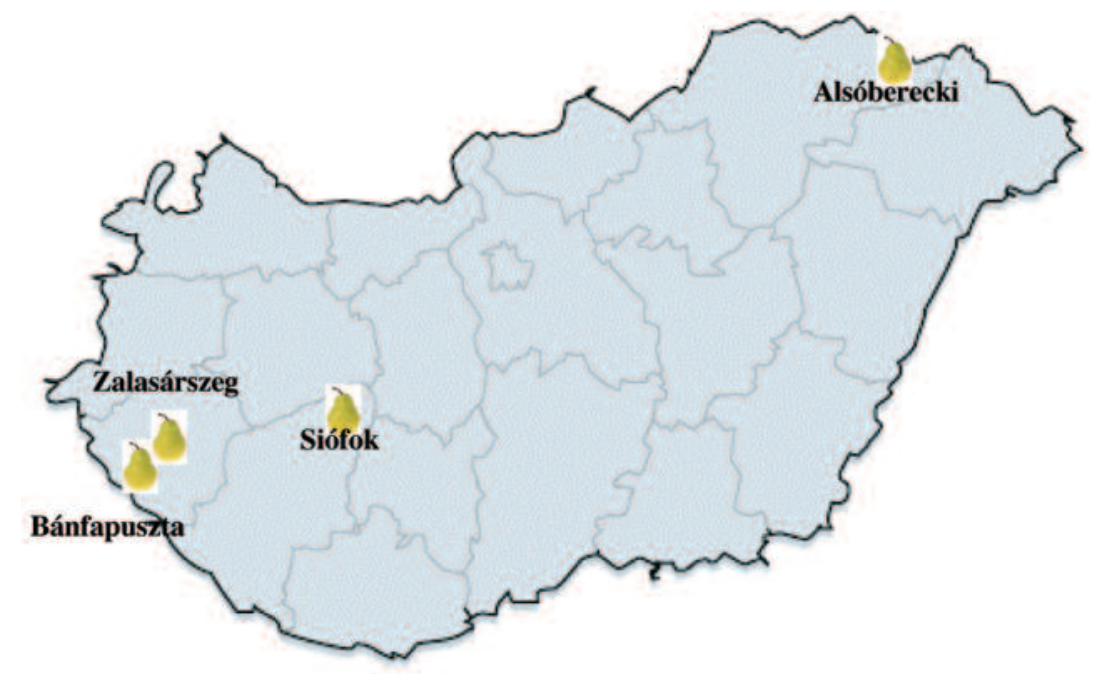

Figure 2. The examined plantations 'Bosc Beurre' and 12 ha of 'Williams' orchards there. The orchard in Zalasárszeg planting design is $9 \times 5 \mathrm{~m}$. Trees were trained to spindle. Plantation is grassed and non-irrigated.

\section{- Bánfapuszta}

Bánfapuszta plantation is also situated in south-western Hungary. 'Williams' and 'Bosc Beurre' were grown on 44.5 ha and 32.3 ha in 1994 , respectively, while the areas of the plantations are now 15.7 ha and 18.5 ha. Planting design of Bánfapuszta is $6 \times 4 \mathrm{~m}$. Trees are spindle shaped without support system and the plantation is grassed and nonirrigated.

\section{- Alsóberecki}

Alsóberecki can be found in Borsod-Abaúj-Zemplén County, 85 kilometres northeast of Miskolc, in the Bodrog River valley. The plantations were planted in 1974 and 1975. There are 25 ha of 'Bosc Beurre' and 8 ha of 'Williams' orchards there. The trees are trained to hedgerows with slanting branches. Its crown shape is bushy, a wild type of fruit tree, 'Bosc Beurre' was grafted on seedings, 'Williams' grafted on quince.

\section{- Siófok}

Siófok is situated in Transdanubia, on the south-eastern side of Lake Balaton. The surface is slightly rolling with west-facing slopes and no groundwater to a depth of $200 \mathrm{~cm}$. Its ecological characteristics are excellent, with almost no frost risk. The entire area can be irrigated. The pear orchard is 5.5 ha and was first planted in 1988. The main variety is 'Williams' with 'Clapp' as polliniser. Both varieties are grafted to quince, trained to spindle.

\section{The method of the risk analysis}

During our analysis, we used the mean-variance (E-V) efficiency method, first and second degree stochastic dominance (FSD, SSD), as well as those general stochastic dominance methods which consider the intensity of risk aversion of decision 
makers. With the help of these methods, the yield risks on four different plantations were compared (Persely et al., 2010).

\section{Results}

We used the E-V efficiency criterion to compare the yield risk of four different plantations (Bánfapuszta, Zalasárszeg, Alsóberecki and Siófok) and two pear varieties ('Williams', 'Bosc Beurre') (Figure 3). The efficient set contains the points of the alternatives in the north-west quadrant, which is empty. From among the examined variations, the 'Williams' and 'Bosc Beurre' varieties cultivated in Bánfapuszta, as well as the 'Williams' cultivated in Siófok, do not belong to the efficient set. Since from among the examined alternatives only some of these may be placed in any determinable order, we calculated the first and second degree stochastic dominances.

In Figures 4 and 5, we can see the results of the first and second degree stochastic dominance. In Figure 4, the distribution functions cross each other, so again only partial dominance can be proved between the alternatives with this method. We cannot define the alternative(s) with the less yield risk exactly; however, we can see that the distribution functions of Alsóberecki alternatives are located to the right of the other distribution functions on almost the whole domain. Moreover, the slopes of the distribution functions above the 0.1 probability range seem to be higher than the ones of the other functions, which indicates higher expectations with lower variances and therefore relatively lower risk.

In order to determine the ranking of alternatives, one must employ the second degree stochastic dominance method (Figure 5). It can be seen that 'Williams' has the smallest yield risk in Alsóberecki, since the integral of its distribution function lies everywhere below and to the right of the other curves. It is followed by the 'Bosc Beurre' in Alsóberecki and by the 'Bosc Beurre' in Bánfapuszta. However, with the help of the second degree stochastic dominance we cannot show total ordering as some curves still cross each other. Nevertheless, the general stochastic dominance method is applied not only for the total ordering but also for considering the risk aversion of the decision maker.

If we represent the certainty equivalent (CE) curves with the help of the general stochastic dominance method, we can compare the four different plantations and the two pear Beurre')

\section{$E$ - $V$ efficiency}

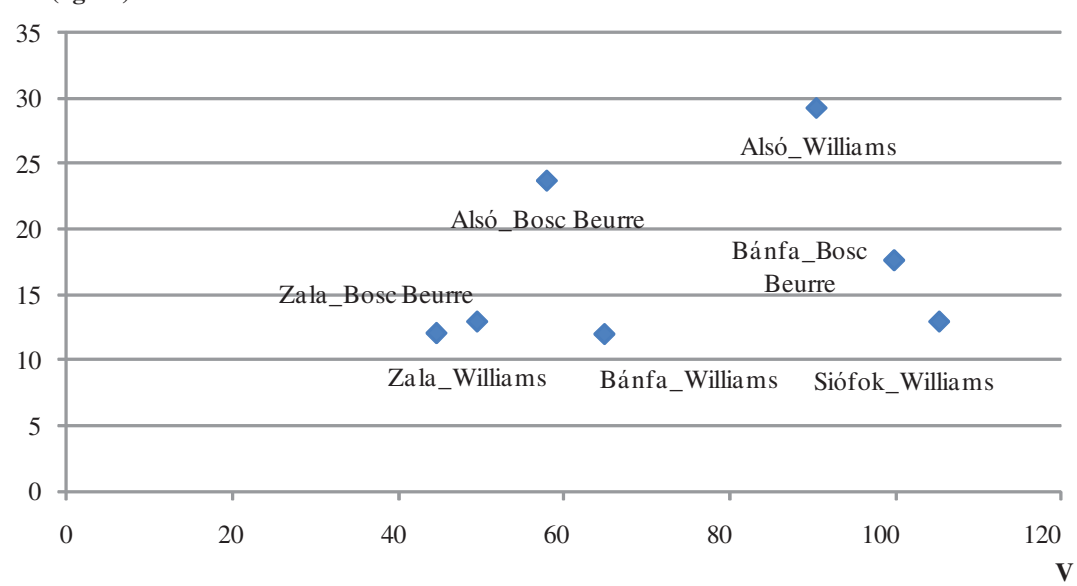

Figure 3. E-V efficiency for four different plantations and two pear varieties ('Williams' and 'Bosc

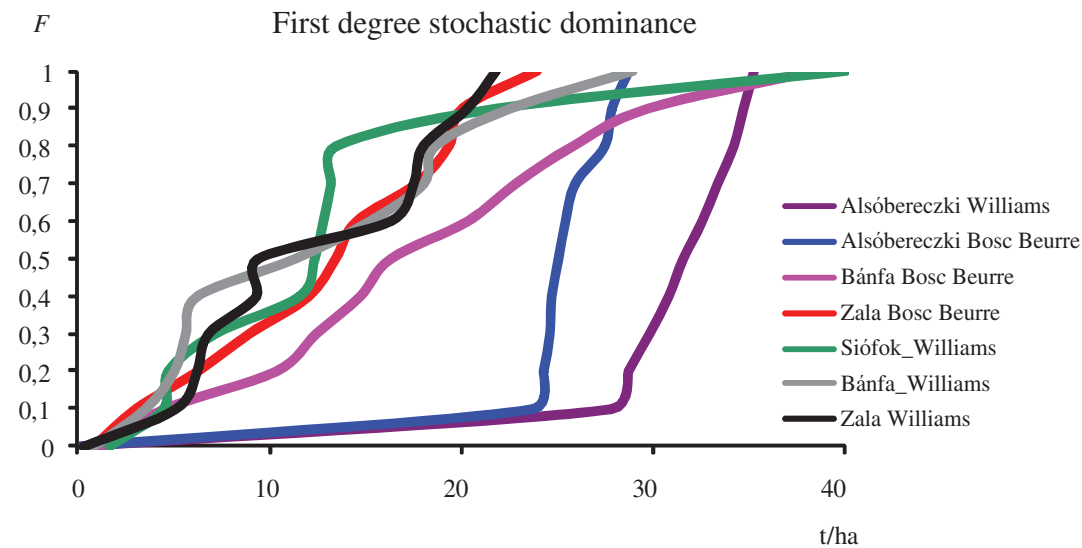

Figure 4. Illustration of first degree stochastic dominance. The distribution functions are for the yield of four different plantations and to 'Williams' and 'Bosc Beurre' pear varieties

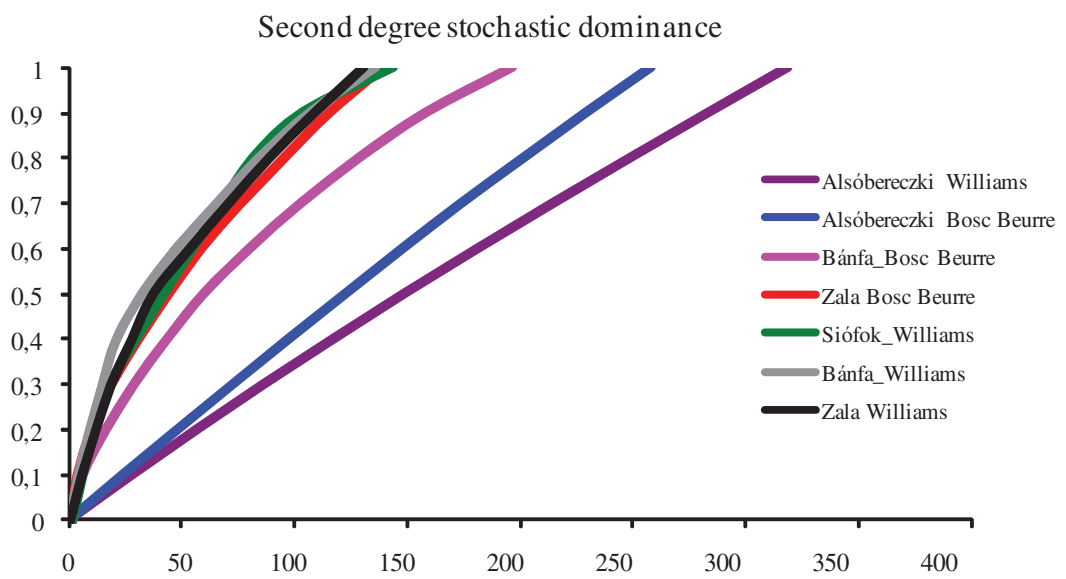

Figure 5. Illustration of second degree stochastic dominance for the yield of the examined four plantations and for the two pear varieties.

varieties according to their yield risk. The main advantage of this method is that the decision makers' personal attitude towards risk can also be considered. The higher the CE curve of the risk aversion lies the lowest risk the alternative contains (Persely et al., 2010). 

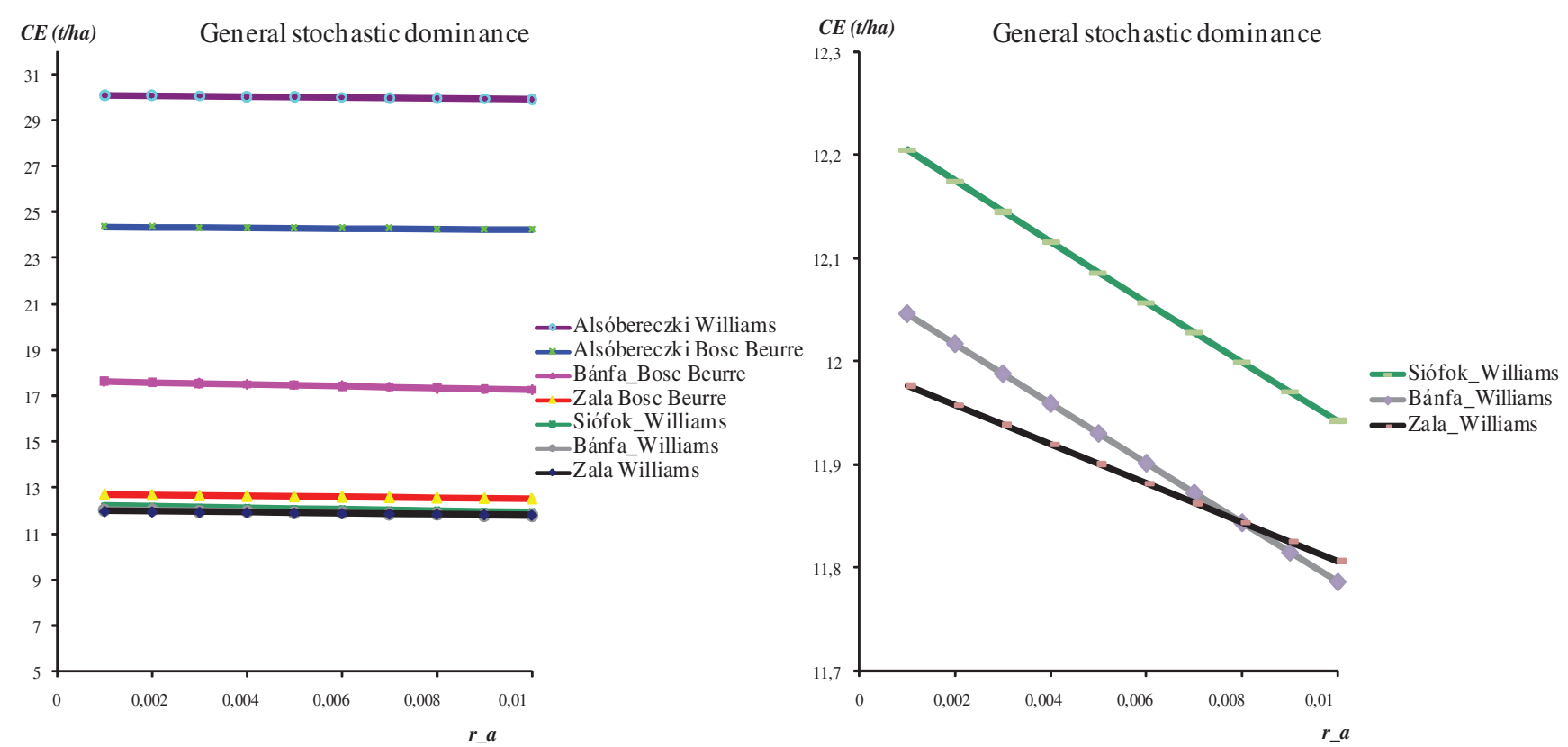

Figure 6. Certainty equivalent curves for the yield risk of the examined four plantations and for the two varieties, depending on the risk aversion value $\left(r_{a}\right)$ of the decision maker

As can be seen in Figure 6, on the left, the CE curve of variety 'Williams' from Alsóberecki lies the highest, so this alternative has the lowest yield risk. This alternative is followed by 'Bosc Beurre' from Alsóberecki, Bánfapuszta and Zalasárszeg. The enlarged CE curves of variety 'Williams' from Siófok, Bánfapuszta and Zalasárszeg are displayed in Figure 6, on the right. As can be seen on this figure, if the risk aversion is low $\left(r_{a}<0.008\right)$, the better alternative is 'Williams' from Bánfapuszta, while in case the risk aversion is higher $\left(\mathrm{r}_{\mathrm{a}}>\right.$ 0.008), 'Williams' from Zalasárszeg is the better alternative for the decision maker.

\section{Acknowledgements}

Herewith we would like to express our thanks to Miklós Csengő, József Szukics, Gyula Sipos and Cecília KonrádNémeth for their inspiration and assistance, and to the research projects: OM-00042/2008, OM-00265/2008, OM-00270/2008 for supporting the research.

\section{References}

Drimba, P. \& Nagy, J. (1997): Kukoricahibridekkel végzett kockázatvizsgálat eredményei. Növénytermelés, 46 (5): 487-499.

Drimba, P. \& Nagy, J. (1998): A talajművelés hatásának eredményei a kukoricatermesztésben a kockázat figyelembevételével. Növénytermelés, 47 (1): 59-71.
Drimba, P. \& Nagy, J. (2000): Kukoricahibridek termesztési arányának meghatározása a hozam kockázatának csökkentése érdekében. Növénytermelés, 49 (1-2): 89-94.

Drimba, P. \& Ertsey, I. (2003): Bizonytalansági és kockázati kritériumok alkalmazása a műtrágyázás kukorica hozamára $\mathrm{v}$ aló hatásának vizsgálatához, Agrárgazdaság, vidékfejlesztés és agrárinformatika az évezred küszöbén, (AVA konferencia) Debrecen

FAO,

http://faostat.fao.org/site/567/DesktopDefault.aspx?PageID=567\#a ncor

G. Tóth, M. (2001): Gyümölcsészet. PRIMOM Sz-Sz-B. Megyei Vállalkozásélénkítő Alapítvány Vállalkozói Központ, Nyíregyháza, 108-162. p.

Göndör, J.-né (1998): Körte. (In: Soltész M. (1998): Gyümölcsfajta-ismeret és -használat.) Budapest, Mezőgazda Kiadó, 1998. pp. 156-186.

Göndör, J.-né (2000): Körte. Mezőgazda Kiadó, 117-129.

Göndör, J.-né (2001): Körte. (In: G. Tóth M. (2001): Gyümölcsészet.) PRIMOM Sz-Sz-B Megyei Vállalkozásélénkítő Alapítvány Vállalkozói Központ. Nyíregyháza. 108-143 p.

KSH (2007): Magyarország mezőgazdasága 2007.

Ladányi, M. (2006): Folyamatszemléleti lehetőségek az agroökoszisztémák modellezésében, Budapesti Corvinus Egyetem, Matematika és Informatika Tanszék, Doktori (PhD) értekezés, Budapest

Soltész, M. (2004): Körte. Alany- és fajtahasználat. (In: Papp J. (szerk.): A gyümölcsök termesztése 2.) Mezőgazda Kiadó. Budapest. 121-150. p. 